\title{
Female-style Beksan Nir Corona Dance as Symbol for Coronavirus Prevention in the Perspective of Javanese Philosophy
}

\author{
Lidya Permata Sari*, Erna Andriyanti' Kusnadi
}

Faculty of Languages and Arts, Yogyakarta State University, Yogyakarta, Indonesia

*Corresponding author. Email: lidya.permata.880@gmail.com

\begin{abstract}
The Covid-19 pandemic caused by the coronavirus is a global problem that occurs in almost all countries, including Indonesia. As the virus transmission is based on human contact, it is important to maintain the cleanliness and sanitation of the body, especially the hands. This becomes the basis of creation for the Beksan Nir Corona dance. This study was based on semiotics and visual hyperreality to analyze the dance. The dance was originally created for a virtual dance competition to commemorate the anniversary of Jumenengan Dalem Sri Sultan HB X. However, the Yogyakarta Palace used the dance to promote hand washing to address the pandemic. This study examines how the forms of motion in Beksan Nir Corona are presented, using qualitative method with a semiotic approach and Pierce's theory on the analysis of signs $(\mathrm{T})$, objects $(\mathrm{O})$ and interpretants $(\mathrm{O})$. The dance elements which are interrelated and produce symbolic meaning are seen as signs that are processed visually, verbally and cognitively. The analysis shows that at the beginning of the dance there is a gesture of worship to pay respect to God and the Sultan of Yogyakarta, followed by a series of hand washing motions as recommended by WHO. The dancer's eyes project confidence and the seriousness of her craft and in washing hands. The motion patterns are brought together by a connecting motion to create a complete dance piece depicting the steps of washing hands.
\end{abstract}

Keywords: Motion, Female-style beksan nir corona, Virus prevention symbol, Javanese philosophy perspective

\section{INTRODUCTION}

Presently, the world is shaken by the Covid-19, a deadly disease caused by the novel coronavirus (nCoV2019), which first emerged in 2019 in Wuhan, China [1] [2]. Humans with no immunity against the virus can be infected.

The Covid-19 transmission process typically begins with direct contact with infected people through the spray of saliva [2]. Transmission occurs through droplets from and to the respiratory tract through coughs, sneezes, or exchange of words. Susceptible persons may be infected with the virus once having a direct contact with another infected person [2]. Pathogen can also be transmitted through the mucus or skin, blood, or fluid which enters membranes of the body, or direct contact with secretion of the pathogen carrier. Transmission may also occur through indirect contact such as objects or contaminated people [2] [3].

The hands are the main medium for the transmission of pathogen of various viruses through direct or indirect contact [2]. It is therefore important to keep the hands clean and hygiene as they may carry dirt and microbes that may enter the human body [3].

The Ngayogyakarta Hadiningrat palace also takes part in promoting the importance of washing hands through a dance called Beksan Nir Corona. Beksan Nir Corona was initially performed virtually in social media in a public competition. The dance was originally created for KHP Kridho Mardowo to commemoratethe $32^{\text {nd }}$ Jumenengan Dalem of Sri Sultan Hamengku Buwono X. However, the coronavirus pandemic inspired the creator to shift the function of the dance as a part of the effort to prevent the coronavirus transmission.

This study used the semiotic approach relevant to the coronavirus transmission prevention.

\section{LITERATURE REVIEW}

Semiotics is a study of the meaning of communicated symbols, and functions as an effort to 
understand the meaning of a creative work which is then communicated through a symbol system to be able to build an art occurence [4]. A philosopher named Charles Sanders Pierce interprets language as a system of symbols consisting of three interrelated parts, namely the representatum, the interpretant (observer), and the object [5]. In the study of art, the role of artists and art connoisseurs as symbolic observers must be considered in order to understand the performance/creation process.

A symbol can be classified into three, namely icon, index, and symbol [5]. It is an icon if it takes the form of the actual object it represents, such as a photograph. If the symbol does not present what it represents, it is called a symbol, e.g. the symbol of Indonesia, which is Pancasila. The last one, index, is when the symbol indicates a follow-up, for example when the smoke is followed by fire.

Semiotics can be used to exaplain the problem of symbols, including the use of symbols, the meaning of the message, and the way it is conveyed [6]. There is a triangular relation between symbol, object, and meaning [7]. Symbol is used to represent object that is symbolized, while it is the interpretant which associates the symbol with object and meaning. In this case, interpretant functions as a facilitator between the symbol and the represented object. As a result, the meaning of the symbol is merely a manifestation of the interpretant once the interpretant associates the symbol with the object. The relation between thought, symbol, and the referred object to generate meaning is related to the notion of how arbitrary the relation between the symbol and the object is [8]. The definition of a symbol may change constantly based on the public's desire and condition [9]. Figure 1 below depicts the triadic model and the trychonomy concept.

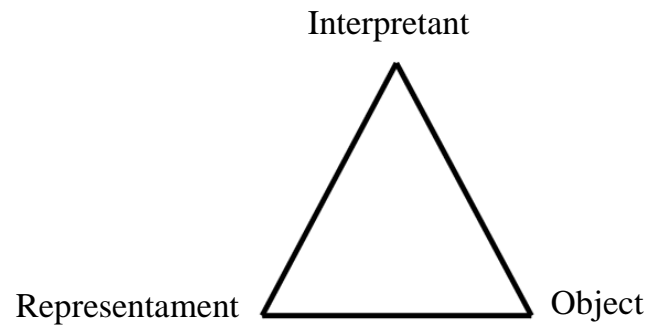

Figure 1. The triadic model and the trichonomy concept (Vera, 2014:21)

To study an object, one must consider the following trichonomy concept [5]:

1. Sign (Representament) is the physical form or anything that can be processed by the five senses and refers to something. The first trichotomy can be divided into three aspects: a) Qualisign is a sign that becomes a sign based on its nature. For example, the nature of red color as a qualisign is that it can be used to represent love, danger, or restriction. (2) Sinsign refers to signs which becomes signs based on the actual form or appearance in reality. All individual speech can become sinsign. A scream can mean wonder, joy, or pain. (3) Legisign is sign that is based on a regulation which applies generally or a convention or a code. All language signs are legisign, because language is a code. Each legisign contains sinsign which connects the second thing with the third, namely rule that applies generally.

b) Object. Sign can be grouped into icon, index, and symbol (1). Icon is a sign which resembles the object it represents or a sign which uses the similar attributes or features with what it conveys. For example, the way a map shows the geographical rarea it depicts. Photographs are also an example of this. (2) Index is a sign with characteristics which depend on the existence of a denotation. In Peirce's terminology it is a secondness index, namely a sign that has a connection or closeness to what it represents. (3) A symbol is a sign, in which the relationship between the sign and its denotation is determined by a generally accepted rule or determined by a collective agreement.

c) Interpretant. Signs are grouped into rheme, dicisign, and argument. (1) Rheme: when the interpretant of a symbol is a first and the meaning of the symbol can still be developed. (2) Dicisign (dicentsign): when there is a truly existing relation between the symbol and interpretant. (3) Argument: when the interpretant of a symbol has a characteristic that is generally accepted (thirdness).

The symbolic process has dependence value, detachment, and prominence [8]. The values that show the symbolic system can affect and be affected so that the symbol works. There are symbols affected by other symbols. The dominant or prominent symbols are the ones affecting symbols with dependence value.

The process of understanding symbols in a dance performance is linked to a certain system which combines one symbol with another. Each unit in the symbol cannot stand alone to deliver the message.

Veltrusky [10] states that everything in performance is a symbol, and that all the objects and the attitudes of the performers have a relation with the related objects. This means that non-literal symbols must be able to be utilized in a literal manner so that the message can be received/interpreted by the audience/public.

Symbols and the things they represent are not necessarily (not absolute) related to each other because 
symbols are dynamic by nature [10]. For example, the dance motions that imitate a bird flying can either become a symbol for a bird, or a symbol of freedom in another context. In an art performance, whether theatre or dance, non-verbal symbols exist within a system of symbol which consists of physical characteristics, facial expressions, gestures, touch, environment, and the use of space and time. In addition, dance is a set of complex symbols with the objective of using the body as the medium [11]. The performance narrative can be considered as a macro symbol which can be divided into smaller units before conducting analysis. Performance should not be judged as a single symbol, but as a network of semiotic units within which interrelated systems exist.

\section{RESEARCH METHODOLOGY}

This is a descriptive qualitative research. Qualitative research is a method used to study the natural condition of a certain object (as opposed to experiments), and the researcher serves as the key instrument [12]. The data collection technique was a triangulation (combination), while the data analysis was inductive. The result of qualitative research stresses more on meaning than generalization.

Semiotic approach in the Javanese philosophy perspective was applied in this study. Dance is viewed as a sign consisting of the elements of motions with all the varieties. These elements are related to each other and generate a symbolic meaning. The research analysis focuss on the art creation in which the explanation uses words on intra-aesthetic and extraaesthetic content. Pierce's theory was used as a reference to study the beksan through observation on the icon, index, and symbol to draw conclusion on the real meaning [5].

\section{FINDINGS}

Overall, the presentation of Beksan Nir Corona consists of three parts, both for the male and female style. They are sembahan or maju beksan, how to use hand sanitizer, and how to apply it on hands. In otder to read the visual object of Beksan Nir Corona, Pierce's semiotic approach is used [5], i.e. representation (sign = T; something), object $(\mathrm{O}$; based on human cognition $)$, and interpretation ( $\mathrm{I}$; interpretation process). The following is the analysis of semiotic study based on Pierce's theory applied on the female-style dance motions of Beksan Nir Corona.

\subsection{Maju Beksan}

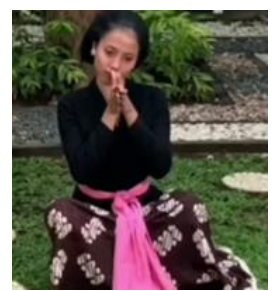

Figure 2. Representament sembahan sila panggung (Kraton, 2020)

The stance depicted in Figure 2, sila panggung, is marked by a straight posture of the body, sitting on the floor and the legs crossed. Thumbs are brought close to the nose, palms closed together, making a $30^{\circ}$ angle. Pacak gulu is done by tilting the head to the left and right and back to the center. The sitting position resembles a meditating person to focus on the self. Both hands are brought together as a symbol of the unity of views and perceptions between the heart and the mind to focus on one central point. Pacak gulu represents balance, that is always in the center and has two meanings: first as a sign of honor, as the fingers pointing diagonally toward the king, and secondly, as a prayer and symbol of the human weakness, and proof of the existence of God Almighty.

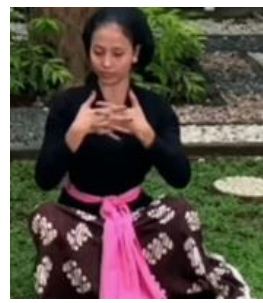

Figure 3. Representament sembahan sila panggung (Kraton, 2020)

Figure 3 above shows a stance where the palms are brought together with the fingers overlapping each other facing the body right in front of the chest, resembling hands stretching as if getting ready for activities. The hand position that is right before the chest represents where the human heart is, suggesting the seriousness or readiness to conduct an activity with genuine intention which comes from the heart. Sembahan is followed by stretching the palms facing the dance right on the chest, which is where the manah (heart) as the place where there is an intention to begin an endeavor (to clean all things that are considered not good even in invisible gaps). In this case, because the object that is considered bad is the coronavirus, the motion represents cleaning through hands with the intention of the dancer to kill the virus. 


\subsection{Udhar Sembah}

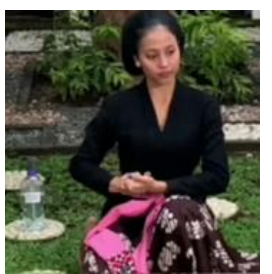

Figure 4. Representament Udhar Sembah (Kraton, 2020)

The signifier can be seen from the hand sanitizer on the right side of the dancer, as is depicted in Figure 4. The motion begins by squirting the hand sanitizer on both hands, and holding the hand sanitizer with both hands. The right hand represents the direction of the good. The use of hand sanitizer marks the beginning of hand-washing motion. The hand forming a fist represents the symbol of unity, solidarity, or strength. Together, all these motions can be interpreted as the depiction of the noble objectives which will be obtained together, coming as one to do good.

\subsection{Sendi (Connecting Motion)}

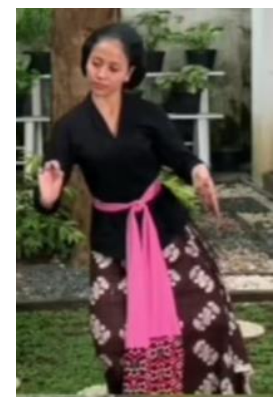

Figure 5. Representament Sendi (Kraton, 2020)

Figure 5 above shows a connecting motion, which is used to mark the change of the dance pattern as a symbol of connecting one part to another, just as the human's bones connected by joints (sendi). This motion depicts a relation bound to achieve a goal.

\subsection{Main Motion}

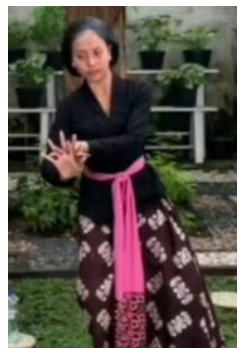

Figure 6. Representament Main Motion 1 (Kraton, 2020)

The dancing stance in Figure 6 begins with the hand-washing motion of cleaning the in-between fingers, followed by tilting the head, the fingers open, and one hand is put on top of another hand with the fingers intertwined. This is done in turns between left and right and represents the relation of helping one another among people. The heads tilting left and right represent balance, while the overlapping hands and fingers are meant to convey that the seemingly insignificant small things (the gaps between the fingers) are sometimes the ones which can lead to a bigger problem if ignored.

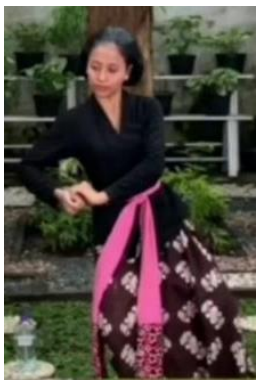

Figure 7. Representament Main Motion 2 (Kraton, 2020)

The motion in Figure 7 above is marked by two hands holding on to one another with the motion of cleaning the inner part of the hands. One hand resembles a hook to symbolize a connector, a trap, or an object that is used to catch something. This is interpreted as the interrelation between one another and the power of connection in helping or supporting each other.

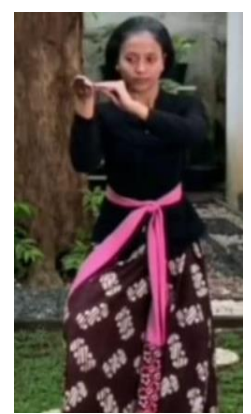

Figure 8. Representament Main Motion 3 (Kraton, 2020)

The left hand forms a pointed gesture (nyucuk) to the right hand and vice versa. The cleaning motion is done on the ends of the fingers and the palms. The stance in Figure 8 above, Nyucuk, is a symbol of the beak of a pecking bird, while the fingers pointed below also depicts the act of giving. In addition, the open hands (mlumah) represent the gesture for asking and the weakening human condition. The hand forms are interprented as the act of giving and receiving. The fact that it is done in turns mean that nothing lasts forever, as sometimes those who give may also be in the position of asking or receiving at one point of their life. 


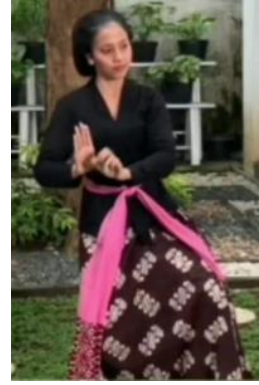

Figure 9. Representament Main Motion 4 (Kraton, 2020)

Figure 9 above shows a dancing stance where the right hand is in an upright position (baya mangap), while the left hand holds the the right hand's thumb in a spinning motion as a sign of cleaning the thumb. The upright position of the finger represents the belief in God. In Javanese, the thumb is the symbol of excellence, while the holding hand represents a protection. This means that success (an outstanding one) comes from God as a result of maintained and continuous efforts.

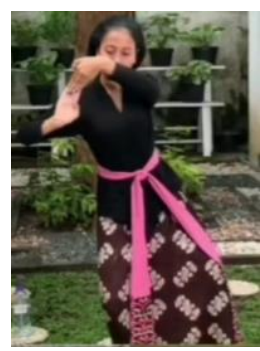

Figure 10. Representament Main Motion 5 (Kraton, 2020)

Figure 10 above depicts a motion pattern of slapping the hand in turns marks the end of the cleaning activity or process. The last part of a cleaning process also signifies a sense of tawakal or letting go and relying on God after all the efforts done.

The icons, objects, and symbols after the sendi motion are all the procedure of cleaning hands using hand sanitizer that $\mathrm{h}$ has been approved by the WHO. In each transition of motion, sendi is used as a connecting motion, resulting in a complete unified piece. The body position of the dancer moves by leaning (hoyog) to the left and right while simultaneously staying still in the same position. The development pattern of the hand washing motions of 1 to 5 was done implicitly according to the correct way procedure of hand washing so that the public can easily understand the correct steps of washing hands. However, the motions ultimately also reveal deeper meanings as interpreted by the motion symbols.
The eyes of the dancer from the beginning to end must show her seriousness in concentration, in this case in doing the activity of washing hands in the correct manner. This can be seen from the sharp look in her eyes, looking straight, facing the floor, with the chin in the same direction as the eyes.

\section{DISCUSSION}

At first, Beksan Nir Corona was created to commemorate the anniversary of Jumenengan Dalem Sri Sultan HB X. However, the unexpected circumstances have forced the competition to be adjusted into a virtual one to educate the public on the correct way of washing hands to prevent the spread of the coronavirus.

Based on the motion analysis of Beksan Nir Corona by referring to the icons, index, and symbols, it can be concluded that the pattern of motions of Beksan Nir Corona is developed from the hand washing motions which become a whole unified piece without leaving even one part to ensure that the virus that may be present on the hands be completely removed. In the perspective of Javanese philosophy, the beksan contains meaning, which is that all the efforts done by the community, including washing hands, must be done seriously and earnestly toward God. The efforts must be done hand-in-hand among all levels of the society to help and protect one another. These efforts must be done continuously with intensity and seriousness so that the problems will soon be resolved. In the last part of the dance, the motion represents the sense of tawakal or relying fully to God for all the efforts of the community.

The dance motions which adopt the hand-washing procedure are developed implicitly so that they can be easily understood by the public. When all these elements can be accepted and applied in real life, it is expected that the activity may break the chain of the coronavirus transmission. With all the elements of the society learning the dance, they are expected to understand the profound meaning in the dance motions. Therefore, the educational function in the dance can be properly conveyed and applied in the day-to-day life of the community, ultimately contributing in the effort of preventing the coronavirus transmission.

\section{REFERENCES}

[1] F.S. Agiesta. Cerita Lengkap Asal Mula Munculnya Covid-19 di Wuhan [The Origin of Covid-19 in Wuhan], Merdeka.com, https://www.merdeka.com/dunia/ceritalengkapasal-mula-munculnya-virus-corona-diwuhan.html. Accessed 15 September 2020. 
[2] Zhou, P., Yang, X. L., Wang, X. G., Hu, B., Zhang, L., Zhang, W., ... \& Shi, Z. L. A pneumonia outbreak associated with a new coronavirus of probable bat origin. Nature, vol. 579, no.7798, 2020, 270-273.

[3] Handwashing Liaison Group. Hand washing: A modest measure — with big effects. BMJ, 1999. DOI: https://dx.doi.org/10.1136\%2Fbmj.318.7185.686

[4] Bakar, A. L. A. Aplikasi teori semiotika dalam seni pertunjukan [The application of semiotic theory in the performing arts]. Etnomusikologi (Jurnal Ilmu Pengetahuan dan Seni), vol. 2, no. 1, 2006, 45-51.

[5] Vera, N. Semiotika dalam Riset Komunikasi [Semiotics in Communication Research]. Ghalia Indonesia, 2014.
[6] Berlo, D. K. The Prosess of Communication: An Introduction to Theory and Practice. Holt, Rinehart and Winston, 1960.

[7] Sahid, N. Semiotika untuk teater, tari, wayang purwa dan film. Gigih Pustaka Mandiri, 2016.

[8] Littlejohn, S. W., \& Foss, K. A. Theories of human communication, Waveland press, 2010.

[9] Supardy. Sejarah Filsafat Pendidikan Islam [The History of Islamic Education Philosophy]. Angkasa, 1990

[10] Kobernick, M. Keir Elam, The Semiotics of Theatre and Drama. The American Journal of Semiotics, vol, 1, no. 4, 2008, 103-106.

[11] J.L. Hanna. To Dance Is Human. JSTOR, vol. 13, no. 2, 2014, 32-33. DOI: $10.2307 / 1478407$.

[12] Sugiyono. Metode Penelitian Kualitatif Kuantitatif dan $R \& D$ [Quantitative Qualitative Research Methods and R \& D]. Alfabeta, 2014. 